\title{
LEARNING ABOUT AND LEARNING FROM RELIGION. THE PEDAGOGICAL THEORY OF MICHAEL GRIMMITT
}

\begin{abstract}
Introduction
Until the 1970s, the discourse about religious education was largely conducted by and within Christian traditions, inevitably with a theological and ecclesial emphasis. During the twentieth century, however, the progress of globalisation and patterns of migration to western countries meant not only that the cultural composition of these countries changed, but also that they became and continue to become home to a wide variety of religions and cultural expressions of these religions. The religious educators, scholars and academics of Britain led the religious studies movement, that expanded the field of theory in religious education beyond the domination of the Christian traditions, giving it an inter-faith dimension. Prominent among these religious educators was Michael Grimmitt. In order to understand his contribution to theory, and therefore pedagogy, in religious education three themes from Grimmitt's work are proposed for consideration in this paper. After discussion of these themes, as they apply to Grimmitt's pedagogy, two critiques of Grimmitt's work are presented and evaluated.
\end{abstract}

\section{Religious Education as Education}

Discussion of this theme first does not imply that it is the most important of the themes to which Grimmitt gave emphasis, for all three considered in this paper are of equal importance. However, an examination of Grimmitt's views about the educational nature of religious education shows how, from the time of his 1973 What can I do in $R E$ ? Grimmitt proposed a pedagogy that clearly differed from that of the churches, who up until that time had dominated discussion about religious education (Burgess, 1996). Against the British background in which the Agreed Syllabuses for state schools had been dominated by Christianity and a Christian instruction paradigm (Hull, 1984), Grimmitt argued that the role of the state and the role of the church in the study and teaching of religion were different. He summarised the key difference as that between instructing and educating, with the approach of the churches assuming that Christianity was the answer to people's search for meaning, that the Bible was the inspired vehicle of Revelation, and that the aim of religious instruction was "confessional" (Grimmitt, 1973, p. 18), its intention being to lead the student to commitment to Christianity. On the other hand, he argued, the study of religion in the state school needed to be justified on educational grounds. Drawing on Peters' (1966) view that education was about initiating young people into what is "worthwhile...specific modes of thought and awareness, such as science, history, mathematics, religious and ascetic awareness together with moral prudential and technical forms of thought and action" (p. 50), in 1973 Grimmitt proposed the following criteria for justifying the inclusion of a subject in the curriculum on educational grounds:

- Does the subject incorporate a unique mode of thought and awareness that is "worthwhile" for a person's understanding of self and human life?

- Does the subject widen and deepen the student's perspective in a unique and valuable way and so contribute to human development?

- Can the subject be taught in ways that ensure understanding and foster the child's ability for independent thought? (Grimmitt, 1973, pp. 9-10).

Against these criteria he pointed out that the main educational objection to 'confessional' approaches was that they transposed a particular group of assumptions and pedagogies from the setting where they naturally belonged, the voluntary audience of church or Sunday schools, to the non-voluntary, immature audience of compulsory state education. In keeping with the recently published Schools Council Working Paper 36, (1971) Grimmitt's choice of a structure for content was that of phenomenology. He argued that this approach to the organisation of content in the teaching of religion did introduce students to a "mode of thought and awareness" that had the potential to enhance self understanding and understanding of human life; that it did help to widen and deepen the student's perspectives in ways that contributed to his or her human development; that it could be used in ways that fostered independent thought. The next section of this paper will deal with phenomenology, illustrating its compliance with these criteria. However, it is informative to note Grimmitt's continued insistence on the justification of religious education in the school curriculum solely on educational grounds in his later writings.

In one of a series of published lectures given at the Conference of the Australian Association of Religious Education in 1978, (the series subsequently became the basis of his 1987 Religious Education and Human Development) Grimmitt developed his claims about the place and 
nature of knowledge about religions in the school curriculum. He claimed that a school curriculum was successful or otherwise to the extent that it set young people "on the way to being receptive to the lessons to be learned from life; of being imaginative and creative in their responses to changing personal circumstances" (Grimmitt, 1983, p. 14). The claim was based on a view of knowledge not as objective, fixed, external to the learner and grasped through the assimilation of a common culture, but as "socially constructed, socially related and socially relative" (Grimmitt, 1983, p. 20). This concept of the hermeneutic between the learner, experience and received 'knowledge' is familiar to educators today, and in some areas of the curriculum it has profoundly affected pedagogy. However Grimmitt proposed this view of knowledge as a social construct particularly in the context of knowledge about religion and religious education. The integration of 'received' knowledge into a personalised, constructed system of meaning that is the result of a dialectical process is described by Grimmitt in this way:

In a society such as ours, everyone has to cope with multiple realities, and reality is not adequately defined only by reference to forms of knowledge or disciplines. The Reality as a Social Construct thesis places Type A knowledge (received, fixed, objectively existing knowledge) within the framework of Type B knowledge (personally and socially constructed knowledge) where it exists alongside other realities especially personal and interpersonal realities.... Bringing the forms of knowledge within a framework of reality which is socially constructed does not rule out that such knowledge is objective, as compared with inter-personal or intra-personal knowledge which is subjective. It does however deny that such knowledge is absolute, and not subject or relative to the social processes that create it (Grimmitt, 1983, p. 23).

The dialectic between personal and social realities and objective or received knowledge, is the basis of the pedagogical approach to religious education which Grimmitt first proposed in 1973, developed in his series of lectures in 1978, developed further in his 1987 Religious Education and Human Development and later in his explication of a social constructivist approach to religious education (Grimmitt, 2000). In 1987 he again questioned the rationalist view of knowledge that it has intrinsic worth. Rather, Grimmitt claimed, knowledge was valuable for its instrumental worth, for what it does. Similarly education and the curriculum are valuable not for any intrinsic worth but for what they do, for their contribution to the goals of education (Grimmitt, 1987). For Grimmitt, the fundamental goal of education is human development in both its personal and social dimensions, and when taken seriously he claimed that this has profound implications for the choice of content and pedagogical approaches, a claim that has particular implications for religious education. .

\section{Phenomenology as a Partner in the Constructivist Pedagogy in Religious Education} The work of Ninian Smart $(1968,1974,1978)$ in phenomenology as an approach in religious education, came to the fore when the state schools of Britain needed an approach to the study of religion that was appropriate to the multicultural and multifaith community that Britain had become. The Butler Act of 1944 had made religious education compulsory in all state schools, and it was to be taught using an 'agreed syllabus' that would be developed under the authority of the Local Education Authority by all of the religious groups represented in the local area. John Hull (1984) has documented the history of the agreed syllabuses, showing that up to 1964 they concentrated on study of the past, particularly through the Bible and examples of exemplary Christian life. In the later 1960s, a perusal of the agreed syllabuses revealed more understanding of the experiential dimension of religious education, but these still saw religious education essentially as education in and about Christianity. Hull (1984. p. 80 ) illustrates the changes that were coming when he quotes from the first of the Syllabuses to attend to the multifaith nature of the British community, the Bath Agreed Syllabus of 1970. "The primary aim of religious eduction is to help young people to understand the nature of religion".

The city of Birmingham was the first to develop a religious education syllabus that took account of the multireligious nature of its population, allowing for breadth of studies of religions as they were represented in the local community, and also for a particular study of one religion if the population of the school required this. The revised Birmingham Syllabus of 1970 was extremely significant for its commitment to " a religious education syllabus that would make a positive contribution to community relations in the city" (Hull, 1984, p. 87), and for the fact that there was a distinction made between the personal religious convictions of the teacher and the syllabus content. The Birmingham syllabus could be taught by any "well informed teacher of good will, regardless of his faith, to any interested pupils, regardless of their faith" (Hull, 1984, p. 88). Hull goes on to observe that after this time, the agreed syllabuses were never as influential as they had been, but he claims, they "give official approval and recognition to trends already 
established" and "register the climate of the subject and set out its norms" (1984, p. 91).

These trends and the climate of religious education in Britain in the 60 s and 70 s were significantly influenced by the work of Ninian Smart (1968, 1974,1978, ) who advocated the study of religion as a means of gaining greater understanding of human experience and of the world in which we live, without "interest in or intention of evangelising" (Lovat, 1995, p. 1). The eminent sociologist of religion, Durkeim (1976), had in the early twentieth century argued for the "scientific or rational" (Nisbet, 1975, p. v) study of religion, applying scientific analysis to its origins, development, and practice from the perspective of an outsider. Smart took up this emphasis, and developed a phenomenological approach to the study of religion drawing on the philosophy of Husserl (1982) who advocated that any apprehension of the experience of being human, or of the world, must begin with the "the natural standpoint, from the world as it confronts us" (Husserl, 1982, p. xix). This apprehension of the world leads through description and analysis to phenomenological reductions, which observe the complex relationships between phenomena, and thus elucidate both the facts and the mystery of human life.

In 1958 Otto's The Idea of the Holy had claimed that religious consciousness or awareness of the sacred existed a priori in the human experience, that is that it was a category of human experience, which "issues from the deepest foundation of cognitive apprehension that the soul possesses, ....it does not arise out of [the data of the natural world] but only by their means" (Otto, 1958, p. 112). According to Otto, this category of the human condition could be studied, as it exists, through description and rigorous analysis. The contributions of Husserl and Otto led to the development of the study of religion as phenomenology (Eliade, 1958; Scheler, 1961; Hick, 1991) and to the work of Ninian Smart who was concemed with "trying to exhibit religion and religions through uncovering the anatomy of Religion" (1973, p. 52). This descriptive, analytical study involved a "bracketing" of one's own religious assumptions in order to enter fully and appreciatively into the religious world of the other.

The phenomenological approach to the study of religion was extremely influential in Britain, and later in Europe and Australia, where it presented a non-judgemental way of studying religions as phenomena of human existence, and thus of contributing to greater understanding and tolerance of the religious groups within a local community. Within his frameworks of an educational justification for the study of religion in state schools, and knowledge as personally and socially constructed Grimmitt adopted Smart's view of religion as a phenomenon that could be studied though its dimensions - experiential, mythological, ritual, social ethical and doctrinal - as a partner in the dialectic that is religious education. Smart had always emphasised the implicit as well as the explicit aspects of religion, that is the presentation of the dimensions of religion in order to bring out their meaning and value for devotees. Grimmitt's pedagogy more clearly brings out this implicit aspect, and seeks to relate religious phenomena to the life worlds of children and adolescents. He demonstrated this in 1973 with his proposal of life themes that he labelled depth, symbol and language themes, situation themes, as able to converse with religious phenomena in a way that enabled the construction of meaning. In 1987 Grimmitt wrote:

Clearly in order to learn about religion one must investigate that part of the arena of faith responses which I have designated 'traditional belief systems' because it is in and through these that religious interpretations of meaning are made explicit in the social world. Equally, however, in order to appreciate the necessary relationship that religious faith responses have to everyday experiences of life, one must also investigate 'shared human experience' (Grimmitt, 1987, p. 204).

In 2000 Grimmitt again enunciated the dialectic between human experience and the content of religions, in his constructivist pedagogy of religious education.

- That the item of religious content is always brought into dynamic relationship with critical and reflective thought.

- That any communication of information is about the item of religious content on the part of the teacher is always related to the constructions that pupils are using, applying and articulating.

- That the sequence of leaming is always from encouraging egocentric interpretations of experience within situated thought, through altemative conceptualised interpretations (as represented by interventions from pupils or teacher) to evaluative judgements about the interests which each interpretation serves and expresses (Grimmitt, 2000, p. 217).

Grimmitt's reasons for giving such prominence to the role of the other partner in the dialectic, the life 
world of the child or adolescent, is explored in the following section.

\section{Why Emphasise Human Experience and Reflection?}

In 1973, against the background of the "God is dead" movement (Altizer \& Hamilton, 1968; Van Buren, 1963) and the first serious attempts to demythologise scripture especially through the Bultmann (1960; 1972) school, Grimmitt questioned the practice of teaching young people traditional Christian thought forms, without reference to the questions that arose from their human experience. Fundamental to this critique was the changing view of God that had arisen through the first half of the twentieth century, and especially the theology of Tillich (1969). Although Grimmitt pointed out that this theology was too complex to be used in the classroom, it gave direction to his emphasis on life questions as a partner in the dialectic about religious education. For Tillich (1969) God was not a removed being, external to human life and experience, and only able to be apprehended rationally (an emphasis that had marked a great deal of Christian theology). Instead God was 'depth'.

The name of this inexhaustible depth and ground of all being is God. . translate it and speak of the depths of your life, of the source of your being, of your ultimate concem, of what you take seriously without reservation. Perhaps in order to do so you must forget everything traditional that you have learned about God, perhaps even the word itself. For if you know that God means depth, you know much about him (Tillich, 1969, p. 63).

In other words, the truth at the heart of any religion is disclosed in and through people's own experiences. This was true, Grimmitt claimed, even of traditional dogmas, for they are made valid only when the person apprehends that they point to, or "square with or illuminate" (Grimmitt, 1973, p. 52) the person's experience. Any religious phenomenon is only valid for the individual if it is able to speak directly to his or her existential situation. Herein lies the dialectic that is at the heart of religious education pedagogy. "God is not "out there'.... he is the "beyond in the midst of our life"" (Robinson, 1963, p. 47). "We need to realise that religious concepts only come alive when we are able to relate them sometimes partially, sometimes completely to our own experiences (Grimmitt, 1973, p. 52)".

On the basis of this fundamental principle of pedagogy, in 1973 Grimmitt proposed approaching religious education through exploration of depth themes or themes that were in keeping with the cognitive developmental stage of the child ${ }^{1}$. These themes explore the child's immediate situation, seeking to uncover the questions within it, and to bring these into conversation with what religious traditions know and teach about these questions. The exploration of depth themes encourages what Grimmitt calls the "frontier questions" (Grimmitt, 1973 , p. 56) and these provide the raw material from which religious concepts emerge.

\section{Illustrating Grimmitt's Pedagogical Approach}

Grimmitt's 1973 book provided a list of possible depth themes for children from primary to secondary school. Some of these were homes and families, people who help us, friends and neighbours, living in groups, things we like to do, highways and joumeys, gifts and giving, books we like to read, experiences of awe, wonder, mystery, courage, sympathy, adventure, kindness, conflicts, disappointment, aggression. The list of possible depth themes is very long since these relate specifically to common human experiences. Unlike the themes proposed by Goldman (1968) depth themes were not meant to bring the child to a particular religious position, but to provide the basis for working towards and exploring general 'religious questions.

According to Grimmitt's 1973 schema, in the middle years of the junior school, symbol and language themes are introduced. These run parallel with depth themes, and they continue through senior primary and secondary school. Symbol and language themes grow out of depth themes and, in taking the initial questions further, they provide the language by which children can begin to understand religious concepts. So the depth theme about things we like to make used in the junior school, may become for older children a symbol and language theme about creation. This theme may be brought into conversation with what different religions teach about creation, and how they understand the creator god and that god's relationship with creation. It may also incorporate further symbol and language themes such as water, desert, birth and rebirth, darkness and light, all of which will provide for further understanding of how these basic themes arise in the beliefs, stories, rituals, and experience of religious communities.

Situation themes, which grow from depth and symbol and language themes are proposed for older

\footnotetext{
'In this 1973 publication, Grimmitt drew on the cognitive development stage theory of Piaget (1969) and the religious stages nominated by Goldman (1968), and these stage theorists influenced education and religious education theory significantly at that time. Subsequent publications of Grimmitt's do not rely on stage theories.
} 
children, senior primary through to senior secondary. These extend the terrain of religious education into moral, personal and social education. Situation themes may be conflict in families, racial conflict, making decisions, how we should we live, values and so forth. A situation theme which may emerge from the depth theme of things we like to make and the symbol and language theme of creation may be our responsibility to the world around us. Such a situation theme, which extends leaming about religions and their beliefs and rituals about creation into the area of moral education, may consider the responsibility of individuals and groups to the environment, and may engage students in considering their own role in conservation. All themes are brought into conversation with appropriate content from world religions.

In his 1987 book Religious Education and Human Development, Grimmitt concentrated on religious education for adolescents. He summarised the theme approach as a dialectic between the adolescent life world (within the four key areas of family, local community, plural society and world wide community), and the world of religions. The knowledge skills and attitudes that are the outcomes of understanding religions and their place in everyday life are referred to by Grimmitt as "abilities in pure religion" (Grimmitt, (1991, p. 77). Those that are the outcomes of the application of religious insights to personal, moral, social development "their frames of reference for viewing life and giving it meaning" are "abilities in applied religion" (Grimmitt, 1991, p. 77). Therefore, themes such as celebrations in the local community will lead to examining the ways in which the religious groups within communities celebrate important festivals, and to knowledge of the stories, beliefs and symbols at the centre of the celebrations. Thus the adolescent's questions about living together in community, understanding other people, and the importance of community, are given a wider and deeper context. The themes deal with ultimate questions such as what is life about?, what do I believe?, what do I value?, how do I relate to my world?, how can I live in community?, and the questions are viewed in relation to the answers given to them by religions. Thus the students' questions are given content upon which they may be sharpened, with the result that new religious understanding is gained.

In his 2000 publication Pedagogies of Religious Education Grimmitt gave a verbatim account of the pedagogical approach. With a group of students he initiated questions about birth and death, the relationship of these two phenomena to each other, about how life could be understood if it is just a process of moving towards death. The conversation with the students moved to issues of creation and destruction, and whether it is possible for human beings to improve their lives. Into the conversation, Grimmitt introduced a photograph of a statue of Shiva as Nataraja, the Hindu dancing god. As Grimmitt explained to the students some of the concepts that surround belief in Shiva, especially the concepts of maya, karma, samara and moksha, concepts are related to key concepts about life and death from a Hindu perspective, and to the regeneration of life, rebirth and one's personal responsibility for one's actions. These were brought into dialogue with the ultimate questions that had begun the conversation, and the students were presented with one religious perspective on these questions.

So what is the truth about human life? The Hindu perspective provided material for the student to develop his or her perspective, so that at the end of the conversation there are new insights for the students, and perhaps new questions. The pedagogy may be summarised in Grimmitt's words:

In my work I have focused particularly on the importance of choosing religious subject-matter with the deliberate intention of providing an opportunity for reflection on, and re-evaluation and interpretation of the self, and of devising a pedagogy which brings the 'religious life world' and the 'adolescent life-world' into a dialectical relationship as a means of promoting this (Grimmitt, 1991, p. 77).

\section{Two Evaluations of Grimmitt's Work}

Kalve (1996) has critiqued Grimmitt's work from the point of view of a theologian. First, he is uncomfortable with religious education being approached from a secular humanist viewpoint, and with the use of phenomenology as an organising structure for content. His objection is that, according to phenomenology, religions are to be treated as equal, recognising however their unique and distinct characteristics. They are valued not for themselves intrinsically, but for what they can do for the learner. However, Kalve (1996) argues, most religious believers would not want this. They see their religious tradition not only as unique but also as revelatory of the truth. Relativism towards the truth claims of religions is, according to Kalve, something religions would want to avoid.

Unfortunately Kalve cites only Grimmitt's 1987 publication Religious Education and Human Development. Had he gone back to the 1973 publication What Can I Do in RE? he would have found a justification for this equality of treatment of religions in a secular humanist approach to religious education. Here Grimmitt insisted that he was proposing a theory and pedagogy of religious 
equation for state schools in a multifaith community. He acknowledged that the needs and intentions of churches and religious communities in religious education were different from those of a government in a secular society, needs and intentions that are translated through a state school system. It is hard to imagine any religious educator arguing that in a multifaith community's state schools, preference should be given to any one religion. To criticise Grimmitt's secular humanist approach to religious education, as proposed for use in a secular humanist society, seems to miss the central point.

Secondly, Kalve (1996) applies a theologian's view to the themes or life questions part of Grimmitt's process. He claims that Grimmitt sees these ultimate questions as essential to the human condition, as human 'givens', and in the human 'givens' category, he puts the capacity to hold religious or other beliefs. Indeed faith response, for Grimmitt (1987, pp. 90-92) is conditioned by the cultural form of religion that the person encounters. Kalve argues, however, that the presence of ultimate questions in the person's reflection on human life, and the capacity to enter into religious faith, are metaphysical capacities, that is they derive from God and are directed towards God.

Kalve's critique of Grimmitt's work is an example of what happens when one approaches the work of another (or enters into the study of religion for that matter) without 'bracketing' one's own context, history, and assumptions. When this is not done, we have the result we find in Kalve's critique, an evaluation, which is heavily slanted towards the particular assumptions and worldview of the one doing the evaluating.

This having been said, Kalve would not have needed to look very far to find something of a theological justification for the human 'givens' in Grimmitt's work, albeit in an earlier work than the one he has cited almost exclusively. In his 1973 work, Grimmitt did argue that life or ultimate questions arose from the depths of the person, and that the 'depth' within the person, according to Tillich (1969), was God. In that work Grimmitt seemed to take the theological view that the process of working towards meaning was a God-inspired one. Kalve may have been more favourably disposed towards Grimmitt's pedagogy had he analysed that particular view, which did not tum up in later works of Grimmitt's.

In a review that was largely favourable to Religious Education and Human Development (Grimmitt, 1987) Greer, (1988) criticised Grimmitt's work on two grounds. The first was Grimmitt's (according to Greer) scarce attention to defining what he means by spirituality. Greer believes that in Grimmitt's work, the reader is left with "a sense of uncertainty about the precise nature of the spiritual" (Greer, 1988, p. 12), and he cites Grimmitt's own uncertainty about where the personal, moral, religious meanings of ultimate questions are distinguishable from the spiritual meanings. Grimmitt is reluctant to delve into these distinctions, and tends to group the spiritual with the religious, moral and to some extent the personal. He is not alone in this, for the search to more clearly make these distinctions is, it could be argued, still in its early stages in educational research. However, the critique is a valid one. We cannot go to Grimmitt's work for a satisfactory definition of the spiritual, but it is the view of this author at least, that this does not necessarily detract from the overall pedagogical approach. 'Most people today would still have difficulties in classifying the kind of ultimate questions with which Grimmitt works as personal, religious, moral or spiritual.

Greer's second criticism of Grimmitt is related to the way in which Grimmitt distinguishes and then, in his pedagogical approach, appears to integrate the forms of knowledge that he refers to as type A and type B (closed/externally verifiable knowledge and socially constructed knowledge), a distinction that has been made at some length earlier in his paper. "Grimmitt attempts to reconcile the two conflicting approaches to knowledge, but he does not do it as clearly as one might have wished (Greer, 1988, p. 13)." This author believes that there are no grounds for such as criticism, and that Grimmitt's integration of the two forms of knowledge in a workable pedagogy is a particularly helpful part of what he has achieved. As shown earlier in this paper, the integration of 'received' knowledge into a personalised, constructed system of meaning that is the result of a dialectical process, is described by Grimmitt:

The Reality as a Social Construct thesis places Type A knowledge (received, fixed, objectively existing knowledge) within the framework of Type B knowledge (personally and socially constructed knowledge) where it exists alongside other realities especially personal and interpersonal realities....Bringing the forms of knowledge within a framework of reality which is socially constructed does not rule out that such knowledge is objective, as compared with inter-personal or intra-personal knowledge which is subjective. It does however deny that such knowledge is absolute, and not subject or relative to the social processes that create it (Grimmitt, 1983, p. 23). 
It is difficult to see what there is about the explanation that Greer finds unclear.

\section{Conclusion}

Michael Grimmitt has made an invaluable contribution to the discourse about religious education and its practice in a secular, multifaith environment. While acknowledging the context for which it is intended, it is argued by this writer that Christian schools can also learn from Grimmitt's approach. His approach is not in conflict with certain tenets of Christian beliefs about revelation, and in his earlier work (1973) Grimmitt has linked ultimate questions with revelation and the revelatory process. $\mathrm{He}$ is in keeping with $\mathrm{Dei}$ Verbum (Abbott, 1966) here, which argues that one ground for revelation is the reality of creation and human life. Arguing as he does from a secular humanist perspective, Grimmitt would probably reject the view that his pedagogy could be of use to Christian schools who want to draw their content particularly but not exclusively from Christianity. Nevertheless, like all educational institutions, Christian schools must respect the religious freedom of the learner. The particular emphasis in Grimmitt's pedagogy on the reflection, judgement, thought processes, search for meaning and identity of the students, and the emphasis on religion being a tool for this, is not far from current thinking about religious education in Christian schools.

\section{References}

Abbott. W. (1966). Dei verbum: Dogmatic constitution on divine revelation. In W. Abbott, (Gen Ed.). The documents of Vatican 11 (pp. 111-128). New York: Guild Press.

Altizer, T., \& Hamilton, W. (1968). Radical theology and the death of God. Harmondsworth Penguin.

Bultmann, R. (1960). Jesus and mythology. London: SCM.

Bultmann, R. (1972). The history of the synoptic tradition. Oxford: Blackwell.

Burgess, H. (1996). Models of religious education: theory and practice in historical and contemporary perspective. Illinios: Victor Books.

Durkeim, E. (1976). The elementary forms of the religious life ( $2^{\text {nd }}$ ed.). London: George Allen \& Unwin.

Eliade, M. (1958). Patterns in comparative religion. London: Sheed \& Ward.

Goldman, R. (1968). Readiness for religion. New York: Seabury Press.

Grimmitt, M. (1973). What can I do in RE? Great Wakering: Mayhew-McCrimmon

Grimmitt, M. (1983). Religious education and humanisation. Sydney: Australian Association for Religious Education.
Grimmitt, M. (1987). Religious education and human development. Great Wakering: McCrimmon.

Grimmitt, M. (1991). The use of religious phenomena in schools: some theoretical and practical considerations. British Journal of Religious Education. 13(2), 7788.

Grimmitt, M. (2000). Constructivist pedagogies of religious education project: re-thinking knowledge, teaching and learning in religious education. In M. Grimmitt (Ed). Pedagogies of religious education (pp. 189-207). Great Wakering: McCrimmon.

Hick, J. (1991). An interpretation of religion. London: McMillan.

Hull, J. (1984). Studies in religion and education. Basingstoke, England: Falmer.

Husserl, E. (1982). Ideas pertaining to a pure phenomenology and to $a$ phenomenological philosophy (F. Kersten, Trans.). The Hague: Martinus Nijhoff.

Kalve, P. (1996). Some aspects of the work of Michael Grimmitt. British Joumal of Religious Education. 18(3), 181-190.

Lovat, T. (1995). What is this thing called religious education? Wentworth Falls, NSW: Social Science Press.

Nesbit, R. (1976). Introduction. In E. Durkeim, The elementary forms of the religious life. ( $2^{\text {nd }}$ ed.). (pp. 1-2). London: George, Allen \& Unwin.

Otto, R. (1958). The idea of the holy. London: Oxford University Press.

Peters, R. (1966). Ethics and education. London: Allen \& Unwin.

Riagete, J. (1969). The psychology of the child. London: Routledge \& Kegan Paul.

Robinson, A. (1963). Honest to God. London: SCM.

Schools Council Working Paper Number 36. (1971). Religious education in secondary Schools. London: Evans Metheun.

Sherrill, L. (1944). The rise of Christian education. New York: Macmillan.

Smart, N. (1968). Secular education and the logic of religion. London: Faber.

Smart, N. (1974). The science of religion and the sociology of knowledge. New Jersey: Princeton University.

Smart, N. (1978). The phenomenon of religion. London: McMillan.

Tillich, P. (1969). The shaking of the foundations. Harmondsworth: Penguin.

*Dr Kathleen Engebretson is a member of the School of Religious Education of Australian Catholic University: she has published widely in the discipline of religious education. 